ANL/CMT/CP-- 88008
CONF-9606116--14 METAL WASTE FORMS FROM THE ELECTROMETALLURGICAL TREATMENT RECEIVED
OF SPENT NUCLEAR FUEL"

Daniel P. Abraham

Argonne National Laboratory Chemical Technology Division 9700 South Cass Avenue Argonne, Illinois 60439 (708) $252-5486$
Sean M. McDeavitt Argonne National Laboratory Chemical Technology Division 9700 South Cass Avenue Argonne, Illinois 60439 (708) $252-4308$
APR 171996

OSTI

Jangyul Park Argonne National Laboratory Energy Technology Division 9700 South Cass Avenue Argonne, Illinois 60439 (708) $252-5030$
The submitted manuscript has been authored by a contractor of the U.S. Government under contract No. W-31-109-ENG-38. Accordingly, the U.S. Government retains a nonexclusive, royalty-free license to publish or reproduce the published form of this contribution, or allow others to do so, for U.S. Government purposes.

Submitted for Presentation at DOE Spent Nuclear Fuel \& Fissile Material Management

Embedded Topical Meeting Spent Nuclear Fuel - Treatment Technologies

Reno, Nevada, June 16-20, 1996

"Work supported by the U.S. Department of Energy, Nuclear Energy Research and Development Program, under Contract No. W-31-109-Eng. 38. 


\section{METAL WASTE FORMS FROM THE ELECTROMETALLURGICAL TREATMENT \\ OF SPENT NUCLEAR FUEL}

Daniel P. Abraham

Argonne National Laboratory

Chemical Technology Division

9700 South Cass Avenue

Argonne, Illinois 60439

(708) $252-5486$
Sean M. McDeavitt

Argonne National Laboratory

Chemical Technology Division

9700 South Cass Avenue

Argonne, Illinois 60439

(708) $252-4308$

\author{
Jangyul Park \\ Argonne National Laboratory \\ Energy Technology Division \\ 9700 South Cass Avenue \\ Argonne, Illinois 60439 \\ (708) 252-5030
}

\begin{abstract}
Stainless steel-zirconium alloys are being developed for the disposal of radioactive metal isotopes isolated using an electrometallurgical treatment technique to treat spent nuclear fuel. The nominal waste forms are stainless steel-15 wt\% zirconium alloy and zirconium-8 wt\% stainless steel alloy. These alloys are generated in yttria crucibles by melting the starting materials at $1600^{\circ} \mathrm{C}$ under an argon atmosphere. This paper discusses the microstructures, corrosion and mechanical test results, and thermophysical properties of the metal waste form alloys.
\end{abstract}

\section{INTRODUCTION}

Electrometallurgical treatment refers to the complete set of operations required to break down spent nuclear fuel and convert the radioactive waste constituents into stable forms suitable for disposal. This process involves electrorefining uranium from chopped fuel pins in a molten salt electrolyte ${ }^{1,2}$ leaving the TRU and fission product behind. Some metallic components of the spent fuel are inert to the electrorefiner environment and are left behind in the anode baskets after the treatment. These remnant metals constitute the metal waste stream, and include fuel cladding hulls, noble metal fission products, and, in some cases, metallic zirconium from nuclear fuel alloys. ${ }^{3}$ These wastes will be stabilized by melting and casting the metals into uniform, corrosion-resistant alloys for eventual disposal in a geologic repository.

Cladding hulls represent the majority ( $>90 \mathrm{wt} \%$ ) of the metal waste stream for every fuel type being evaluated for electrometallurgical treatment. Both stainless steel and Zircaloy clad fuels may be treated, so stainless steel-rich and zirconium-rich waste forms are being developed. The nominal waste form compositions that have been selected are stainless steel-15 wt\% zirconium (SS-15Zr) and zirconium-8 wt\% stainless steel (Zr-8SS), respectively, with each containing up to 4 wt\% noble metal fission products. The addition of external alloying elements to the metal waste form is minimized by using the cladding hulls as the major alloying component.

Stainless steel-zirconium alloys with and without noble metal additions ( $\mathrm{Ag}, \mathrm{Pd}, \mathrm{Ru}$ ) have been prepared in our laboratory to characterize the properties of the metal waste forms. This paper presents the microstructures of the nominal waste form alloys and discusses the results of corrosion studies, mechanical testing, and thermophysical property measurements.

\section{ALLOY PREPARATION}

Small-scale samples $\left(\begin{array}{ll}\sim 20 & \mathrm{~g}\end{array}\right)$ of stainless steel-zirconium (SS-Zr) alloys were generated using type 304 and 316 stainless steels and high purity zirconium. The presence of noble metal fission products in the waste forms was simulated using additions such as ruthenium, palladium, molybdenum and silver. The starting materials were placed in yttria $\left(\mathrm{Y}_{2} \mathrm{O}_{3}\right)$ crucibles, and melted at $1600^{\circ} \mathrm{C}$ in an argon atmosphere for 1 to 2 hours. Details of the experimental arrangement and melting procedure have been provided elsewhere. 4

Large-scale $(\sim 3 \mathrm{~kg})$ ingots of SS-15Zr alloy were generated in an induction casting furnace attached to a controlled atmosphere glovebox. Type 316 stainless steel and zirconium metal rods were charged into 4 in. $(10 \mathrm{~cm})$ diameter yttria crucibles and alloyed at $1600^{\circ} \mathrm{C}$ under high purity argon for $\sim 1 \mathrm{~h}$. Alloy ingots were made by pouring the melt into casting molds or by slow cooling the melt in the crucible itself. These large-scale alloys have been used to prepare specimens for mechanical and corrosion testing. 


\section{WASTE FORM CHARACTIERIZATION}

\section{A. Microstructure and Phase Characterization}

Specimens for microscopic examination were sectioned with a diamond saw, cleaned in methanol and polished to a $0.3 \mu \mathrm{m}$ finish. Initial examination was done with an optical microscope, but most of the analyses were performed using a JEOL 6400 scanning electron microscope (SEM) operating in both secondary and back-scattered electron modes. Standardless quantitative analysis of individual phases was done with an energy dispersive spectrometer (EDS) and Voyager II software from NORAN instruments. The crystal structure of phases was determined by X-ray diffraction; these data were collected with a Philips powder diffractometer using $\mathrm{CuK}_{\alpha}$ radiation.
1. Stainless Stcel-rich Alloys. Stainless steel-rich alloy compositions containing from 5 to $35 \mathrm{wt} \% \mathrm{Zr}$ show varying proportions of the ferritic and austenitic phases of stainless steel and a $\mathrm{ZrFe}_{2}$-type Laves intermetallic, which we have designated $\mathrm{Zr}(\mathrm{Fe}, \mathrm{Cr}, \mathrm{Ni})_{2}+\mathrm{x}^{4}{ }^{4}$ The proportion of $\mathrm{Zr}(\mathrm{Fe}, \mathrm{Cr}, \mathrm{Ni})_{2+\mathrm{x}}$ in the alloy microstructure increases with increasing zirconium concentration until, at about $40 \mathrm{wt} \% \mathrm{Zr}$, the alloy is almost completely intermetallic. Figure 1 shows a mixture of coarse and fine eutectics typical of a SS-15Zr alloy. The dark regions correspond to a high-chromium ferritic stainless steel phase, whereas the bright regions correspond to the Laves intermetallic phase. Small amounts $(<5 \%)$ of an austenite phase (face-centered cubic) and a $\mathrm{Zr}_{6} \mathrm{Fe}_{23}$-type intermetallic were also found in the SS-15Zr alloy.

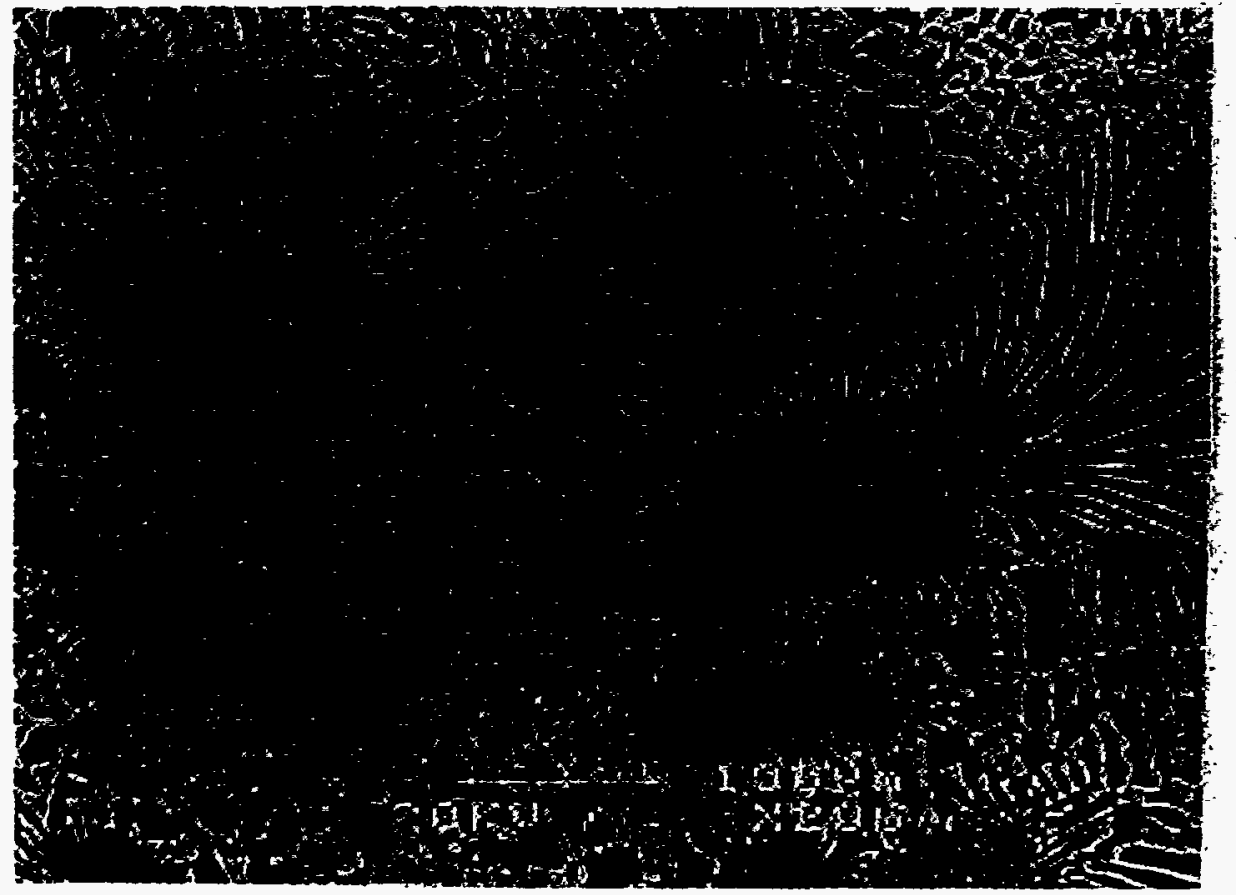

Figure 1. Typical Microstructure of SS-15Zr alloy. The bright phase is the Laves Intermetallic, $\mathrm{Zr}(\mathrm{Fe}, \mathrm{Cr}, \mathrm{Ni})_{2+\mathrm{x}}$. The dark phase is ferrite.

The elemental compositions of phases in the SS-15Zr alloy are listed in Table $\mathrm{I}$. The $\mathrm{Zr}(\mathrm{Fe}, \mathrm{Cr}, \mathrm{Ni})_{2+\mathrm{x}}$ intermetallic contains only 24 at.\% $\mathrm{Zr}$, which is a substoichiometry of more than $25 \%$ from the expected $33 \mathrm{at} . \% \mathrm{Zr}$. This zirconium substoichiometry is also observed in the Laves phases of ternary $\mathrm{Fe}-\mathrm{Cr}-\mathrm{Zr}$ alloys containing from 5 to $35 \mathrm{wt} \% \mathrm{Zr}$. Neutron diffraction studies are being carried out on $\mathrm{Fe}-\mathrm{Cr}-\mathrm{Zr}$ alloys to elucidate the reasons for this zirconium substoichiometry. 
Table I. Composition of Phases Observed in SS-15Zr and Zr-8SS Alloys

\begin{tabular}{|c|c|c|c|c|c|c|}
\hline \multirow[t]{2}{*}{ Alloy } & \multirow[t]{2}{*}{ Phases } & \multirow[t]{2}{*}{$\begin{array}{l}\text { Relative } \\
\text { Proportion }\end{array}$} & \multicolumn{4}{|c|}{$\begin{array}{c}\text { Composition of Major Elements } \\
\text { in at. } \%( \pm 3 \%)\end{array}$} \\
\hline & & & $\mathrm{Fe}$ & $\overline{\mathrm{Cr}}$ & $\mathrm{Ni}$ & $\overline{\mathrm{Zr}}$ \\
\hline SS-15Zr & $\begin{array}{c}\text { Ferrite (body-centered cubic) } \\
\mathrm{Zr}(\mathrm{Fe}, \mathrm{Cr}, \mathrm{Ni}) 2+\mathrm{x} \\
\text { Austenite (face-centered cubic) } \\
\mathrm{Zr} \mathrm{F}_{6} \mathrm{Fe}_{3} \text {-type }\end{array}$ & $\begin{array}{c}\text { Major } \\
\text { Major } \\
\text { Very minor } \\
\text { Very minor }\end{array}$ & $\begin{array}{l}69 \\
54 \\
70 \\
57\end{array}$ & $\begin{array}{c}24 \\
8 \\
20 \\
10\end{array}$ & $\begin{array}{c}4 \\
11 \\
8 \\
9\end{array}$ & $\begin{array}{r}- \\
24 \\
- \\
19\end{array}$ \\
\hline $\mathrm{Zr}-8 \mathrm{SS}$ & $\begin{array}{c}\alpha-\mathrm{Zr} \text { solid solution } \\
\mathrm{Zr}_{2}(\mathrm{Ni}, \mathrm{Fe}) \\
\mathrm{Zr}(\mathrm{Fe}, \mathrm{Cr})_{2}\end{array}$ & $\begin{array}{l}\text { Major } \\
\text { Minor } \\
\text { Minor }\end{array}$ & $\begin{array}{c}3 \\
28 \\
42\end{array}$ & $\begin{array}{c}1.5 \\
- \\
21\end{array}$ & $\begin{array}{c}0.5 \\
5.7 \\
-\end{array}$ & $\begin{array}{l}94 \\
66 \\
34\end{array}$ \\
\hline
\end{tabular}

The addition of noble metals does not alter the microstructure of the SS-15Zr alloy. Noble metal additions of $\mathrm{Ru}, \mathrm{Pd}$, and $\mathrm{Ag}$ were detected in solution for both the intermetallic and ferrite phases. X-ray elemental maps obtained by SEM/EDS revealed that these noble metals exhibit a preference for the Laves intermetallic phase.

The phases observed in the SS-15Zr alloy are in accord with the phases predicted from the $\mathrm{Fe}-\mathrm{Zr}$ phase diagram. ${ }^{5}$ An Fe-15 wt\% $\mathrm{Zr}$ alloy is close to the eutectic composition and is expected to contain a eutectic of ferrite and $\mathrm{ZrFe}_{2}$. The SS-15Zr alloy also shows a eutectic microstructure; the presence of the eutectic implies that the melting temperature (and hence the processing temperature) is lowest for the $15 \mathrm{wt} \% \mathrm{Zr}$ alloy.

2. Zirconium-rich Alloys. Zirconium-rich alloy compositions containing from 50 to $92 \mathrm{wt} \% \mathrm{Zr}$ show a multi-phase mixture of intermetallics and the $\alpha-\mathrm{Zr}$ solid solution. 4 The alloys containing 50 and $67 \mathrm{wt} \% \mathrm{Zr}$ are mainly a mixture of $\mathrm{Zr}(\mathrm{Fe}, \mathrm{Cr}, \mathrm{Ni})_{2+\mathrm{x}}$ and a $\mathrm{Zr}_{2} \mathrm{Fe}$-type intermetallic, which we have designated $\mathrm{Zr}_{2}(\mathrm{Ni}, \mathrm{Fe})$. The proportion of intermetallic phases in the alloy microstructure decreases, whereas that of the ductile $\alpha-\mathrm{Zr}$ increases with increasing zirconium concentration. Figure 2 shows the typical microstructure of a $\mathrm{Zr}-8 \mathrm{SS}$ alloy $(92 \mathrm{wt} \% \mathrm{Zr})$. The "island-like" features in the figure correspond to the $\alpha-\mathrm{Zr}$ phase. The areas between the $\alpha-\mathrm{Zr}$ islands contain a mixture of $\mathrm{Zr}(\mathrm{Fe}, \mathrm{Cr}, \mathrm{Ni})_{2+\mathrm{x}}, \mathrm{Zr}_{2}(\mathrm{Ni}, \mathrm{Fe})$, and $\alpha-Z r$ phases.

The elemental compositions of phases in the $\mathrm{Zr}-8 \mathrm{SS}$ alloy are listed in Table $\mathrm{I}$. The $\alpha-\mathrm{Zr}$ phase contains $\sim 94$, at.\% $\mathrm{Zr}$ and incorporates minor amounts of $\mathrm{Fe}, \mathrm{Cr}$, and $\mathrm{Ni}$. The zirconium content of the $\mathrm{Zr}(\mathrm{Fe}, \mathrm{Cr}, \mathrm{Ni})_{2+\mathrm{x}}$ Laves intermetallic is near its stoichiometric value. In addition, the nickel content of this intermetallic is very small; the phase is hence akin to the ternary intermetallic $\mathrm{Zr}(\mathrm{Fe}, \mathrm{Cr})_{2}$. The noble metal distribution has not yet been quantified in $\mathrm{Zr}-8 \mathrm{SS}$ alloys.

The zirconium-rich side of the $\mathrm{Fe}-\mathrm{Zr}$ phase diagram shows a eutectic at about $84 \mathrm{wt} \% \mathrm{Zr}^{5}$ The melting temperature (and hence the processing temperature) would hence be lowest for an alloy with this zirconium content. The SS-Zr alloys with $84 \mathrm{wt} \% \mathrm{Zr}$, however, contain both the $\mathrm{Zr}_{2} \mathrm{Fe}$-type and the $\mathrm{ZrFe}$-type (Laves) intermetallic phases. Intermetallic-rich alloys are prone to brittleness and may fracture either during fabrication or during storage. Brittle fractures may result in the formation of metallic fines, which increases the alloy surface area and hence the corrosion rate. ${ }^{6}$ The $\mathrm{Zr}-8 \mathrm{SS}$ alloy is enriched in the ductile $\alpha$-Zr phase; this minimizes the probability of brittle fracture and improves the mechanical integrity of the alloy.

\section{B. Corrosion Testing}

Corrosion resistance is the primary performance indicator for the metal waste form. A waste form must survive in a repository environment for an extended duration without releasing its inventory of radioactive constituents to the environment. Immersion corrosion tests in simulated J-13 well water (representative of the Yucca Mountain repository) have indicated that both the stainless steel-rich and zirconium-rich waste form alloys are very resistant to general corrosion. These alloys have retained their shiny surfaces even after $10,000 \mathrm{~h}$ exposure at $90^{\circ} \mathrm{C}$. 


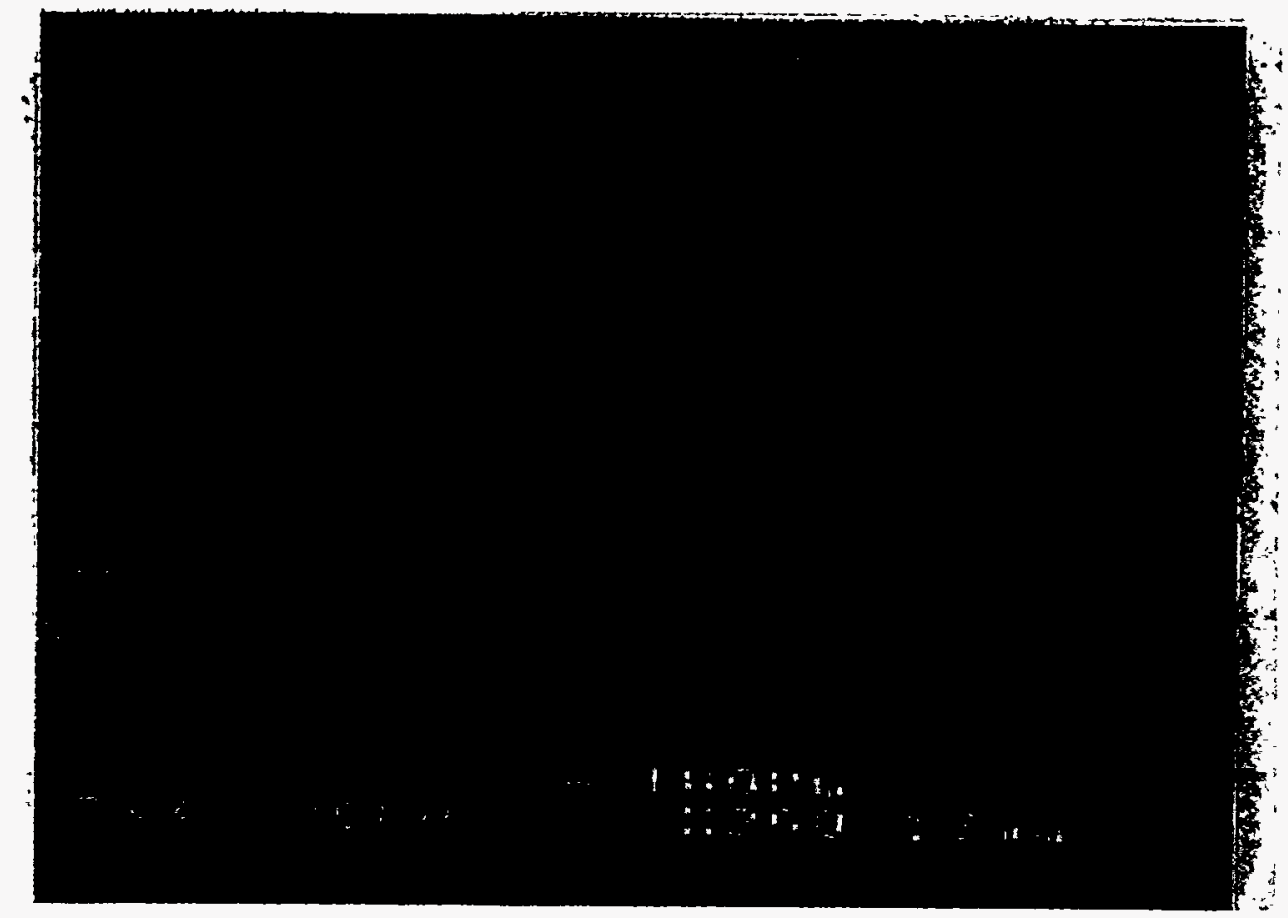

Figure 2. Typical Microstructure of Zr-8SS alloy. The "island-like" features are the $\alpha-\mathrm{Zr}$ solid solution phase. The areas between the $\alpha-Z \mathrm{r}$ islands contain a mixture of $\mathrm{Zr}(\mathrm{Fe}, \mathrm{Cr}, \mathrm{Ni})_{2+\mathrm{x}}, \mathrm{Zr}_{2}(\mathrm{Ni}, \mathrm{Fe})$, and $\alpha-\mathrm{Zr}$ phases.

Rapid estimates of metal corrosion rates can be obtained by electrochemical techniques. Disk specimens (15.9-mm dia and 3-mm thick) were polished to a 600 grit finish and tested in simulated J-13 well water by the linear polarization method. The measured corrosion rates are shown in Table II for the waste form alloys with and without noble metals, commercial zirconium and stainless steels, and selected candidate canister materials. Measurements were made at $\mathrm{pH}=2,4,7$, and 10 to cover a range of potential repository conditions.

The corrosion rates for $\mathrm{SS}-15 \mathrm{Zr}$ and $\mathrm{Zr}-8 \mathrm{SS}$ at $\mathrm{pH}=$ 7 are about the same as the rates for 316 stainless steel and zirconium metal. Also, noble metal additions do not significantly affect the corrosion rates of the waste form alloys. The measured rates for the waste form alloys are also similar to the rate for Incoloy 825 , which is a candidate material for waste form packaging. Additionally, the corrosion rates are smaller than the rate for pure copper (which is a natural analog for the metal waste forms), ${ }^{7}$ and two orders of magnitude lower than the rate for mild steel. Corrosion rates for $\mathrm{Zr}$-rich alloys are not affected significantly by $\mathrm{pH}$ variations, but increasing acidity increases the corrosion rates for stainless steel-rich alloys; these increased rates, however, are still relatively low.

Table II. Corrosion Rates Measured by the Linear Polarization Method

\begin{tabular}{|c|c|c|c|c|}
\hline & \multicolumn{4}{|c|}{ Corrosion Rate (mils per year) } \\
\cline { 2 - 5 } Alloy & $\mathrm{pH}=2$ & $\mathrm{pH}=4$ & $\mathrm{pH}=7$ & $\mathrm{pH}=10$ \\
\hline SS-15Zr & $0.1-0.4$ & $0.08-0.2$ & $0.02-0.08$ & $0.01-0.02$ \\
SS-15Zr-2Ru-1.5Pd-0.5Ag & $0.4-0.5$ & 0.2 & $0.04-0.1$ & $0.06-0.09$ \\
316 Stainless Steel & 0.3 & 0.05 & 0.04 & 0.04 \\
\hline Zr-8SS & $0.02-0.08$ & $0.05-0.06$ & $0.02-0.03$ & 0.01 \\
Zr-8SS-1Ru-1Mo-0.5Pd & 0.08 & 0.04 & 0.03 & 0.01 \\
Zirconium & 0.02 & 0.05 & $0.06-0.09$ & 0.07 \\
\hline Incoloy 825 & 0.03 & 0.05 & 0.07 & 0.03 \\
CDA122 (High-purity copper) & 8.9 & 8.5 & $0.1-0.2$ & 0.4 \\
A106 Grade B steel & 50 & 23 & 12 & 12 \\
\hline
\end{tabular}




\section{Thermophysical Properties}

Information on thermophysical properties is essential for modeling waste form performance. For example, thermal gradients (and hence thermal stresses) in a waste form may cause fractures during fabrication and long-term storage. 6 The presence of thermal gradients is dictated by the material's thermal conductivity and coefficient of thermal expansion. For the same temperature gradient, thermal stresses are lower in a material with a lower thermal expansion coefficient. Thermal gradients and stresses are also lower in a material with high thermal conductivity.

Preliminary experiments to estimate the thermophysical properties (specific heat, thermal conductivity, and thermal expansion) of the SS-15Zr waste form alloy have been performed at the Thermophysical Properties Research Lab (TPRL), Purdue University. Table III compares the room temperature thermal properties of $\mathrm{SS} 316-15 \mathrm{Zr}$ with those of 316 stainless steel, zirconium, and borosilicate glass and Synroc waste forms. The thermal expansion coefficient of SS-15Zr is similar to that for borosilicate glass and Synroc but smaller than that for 316 stainless steel. The thermal conductivity of SS-15Zr is only slightly smaller than the thermal conductivity of 316 stainless steel; however, it is an order of magnitude larger than the value for borosilicate glass, which has relatively poor thermal conductivity. It is evident from Table III that less heat is required to raise the temperature of the SS-15Zr alloy, but the heat is also conducted away rapidly. Thus, thermal gradients and thermal stress fractures are not expected to occur in the SS-15Zr waste form.

\section{Mechanical Properties}

Mechanical test specimens for uniaxial tensile testing and impact testing were produced from our large-scale SS-15Zr ingots. The uniaxial tensile test was performed on round bar specimens with a gage length of 1.45 in $(3.68 \mathrm{~cm})$; the specimens were loaded at an extension rate of $3 \times 10^{-7} \mathrm{in} / \mathrm{sec}\left(8 \times 10^{-7} \mathrm{~cm} / \mathrm{sec}\right)$ at $90^{\circ} \mathrm{C}$ in air. The specimens failed at a tensile fracture stress of $\sim 43 \mathrm{ksi}$ $(\sim 300 \mathrm{MPa})$ and showed less than $1 \%$ elongation. This fracture stress is approximately $30 \%$ higher than that of annealed oxygen-free copper but about $40 \%$ lower than annealed Type 316 stainless steel. The SEM examination of the tensile fracture surface showed that brittle cleavage was the dominant fracture process; ductile fracture processes, such as microvoid coalescence, were not observed.

Table III. Thermal Properties of Various Materials

\begin{tabular}{|c|c|c|c|}
\hline & \multicolumn{3}{|c|}{ Property (near room temperature values) } \\
\hline Material & $\begin{array}{c}\text { Thermal Conductivity } \\
\left(\mathrm{W} \mathrm{m}^{-1} \mathrm{~K}^{-1}\right)\end{array}$ & $\begin{array}{c}\text { Coefficient of Thermal } \\
\text { Expansion }\left(\mathrm{K}^{-1}\right)\end{array}$ & $\begin{array}{c}\text { Specific Heat } \\
\left(\mathrm{J} \mathrm{g}^{-1} \mathrm{~K}^{-1}\right)\end{array}$ \\
\hline SS-15Zr & 12.2 & $11.0 \times 10^{-6}$ & 0.45 \\
\hline 316 Stainless Steel & 14.6 & $16.5 \times 10^{-6}$ & 0.50 \\
\hline Zirconium & 20.0 & $5.6 \times 10^{-6}$ & 0.28 \\
\hline Borosilicate Glass & 1.0 & $8.1 \times 10^{-6}$ & 0.80 \\
\hline Synroc & 2.1 & $10.5 \times 10^{-6}$ & 0.55 \\
\hline
\end{tabular}

Charpy impact tests were also performed on standard notched-bar SS-15Zr specimens at room temperature. The energy absorbed in fracturing the specimens was $\sim 0.8 \mathrm{~J} / \mathrm{cm}^{2}$. Typical cleavage and river patterns were seen on the impact fracture surfaces. The fracture path was mainly through the intermetallic phase, but secondary cracking in the ferrite was also seen. The impact energy of the SS-15Zr alloy is higher than that of simulated nuclear waste glass specimens $\left(0.1 \mathrm{~J} / \mathrm{cm}^{2}\right)$ but much lower than the values for wrought or cast stainless steels, whose impact energies are in the range of 100-200 $\mathrm{J} / \mathrm{cm}^{2}$.

\section{SUMMARY}

Metal waste forms from the electrometallurgical treatment will be either a stainless steel-rich or a zirconium-rich alloy, depending on the composition of the cladding hulls being treated. The major phases in the stainless steel-rich alloy, SS-15Zr, are an iron solid solution (ferrite) and an intermetallic, $\mathrm{Zr}(\mathrm{Fe}, \mathrm{Cr}, \mathrm{Ni})_{2+\mathrm{x}}$. The major phase in the zirconium-rich alloy, $\mathrm{Zr}$-8SS, is an $\alpha-\mathrm{Zr}$ solid solution phase. Small amounts of the $\mathrm{Zr}_{2} \mathrm{Fe}$-type and the $\mathrm{ZrFe}_{2}$-type intermetallic are also present in the $\mathrm{Zr}-8 \mathrm{SS}$ alloy. Noble metal (Ag, Pd, Ru) 
additions do not alter the microstructure of the SS-15Zr alloy; all the noble metal elements are dissolved and distributed in the intermetallic and ferrite phases. Both alloy waste forms show excellent resistance to corrosion and exhibit favorable mechanical properties.

\section{ACKNOWLEDGMENTS}

The authors would like to thank Dr. J. P. Ackerman for his guidance and helpful suggestions during the course of this research. This work was supported by the U.S. Department of Energy, Nuclear Research and Development Program, under Contract No. W-31-109ENG-38.

\section{REFERENCES}

1. J. E. Battles, J. J. Laidler, C. C. McPheeters, and W. E. Miller, "Pyrometallurgical Processes for Recovery of Actinide Elements," Actinide Processing: Methods and Materials, B. Mishra and W. A. Avrill, eds., pp. 135-151, TMS Publications, Warrendale, Pennsylvania (1994).

2. E. C. Gay and W. E. Miller, "Electrorefining N-Reactor Fuel," Proc. DOE Spent Nuclear FuelChallenges and Initiatives, Salt Lake City, Utah, December 13-16, 1994, pp. 267-274, American Nuclear Society, La Grange Park, Illinois (1994).

3. S. M. McDeavith, J. Y. Park, and J. P. Ackerman, "Defining a Metal-based Waste Form for IFR Pyroprocessing Wastes," Actinide Processing: Methods and Materials, B. Mishra and W. A. Avrill, eds., pp. 305-319, TMS Publications, Warrendale, Pennsylvania (1994).

4. D. P. Abraham, S. M. McDeavitt, and J. Y. Park, "Microstructure and Phase Identification in Type 304 Stainless Steel-Zirconium Alloys," submitted to Metall. and Mater. Trans. (1995).

5. D. Arias and J. P. Abriata, "Fe-Zr," Binary Alloy Phase Diagrams, vol. 2, T. P. Massalski, ed., pp. 1798-1800, ASM Intemational, Materials Park, Ohio (1990).
6. W. Lutze and R. C. Ewing, "Summary and Evaluation of Waste Forms," Radioactive Waste Forms for the Future, W. Lutze and R. C. Ewing, eds., pp. 699740, North Holland, Amsterdam (1988).

7. B. Miller and N. Chapman, "Postcards from the Past: Archaeological and Industrial Analogs for Deep Repository Materials," RadWaste Magazine, pp. 3242 (January 1995). 


\section{DISCLAIMER}

This report was prepared as an account of work sponsored by an agency of the United States Government. Neither the United States Government nor any agency thereof, nor any of their employees, makes any warranty, express or implied, or assumes any legal liability or responsibility for the accuracy, completeness, or usefulness of any information, apparatus, product, or process disclosed, or represents that its use would not infringe privately owned rights. Reference herein to any specific commercial product, process, or service by trade name, trademark, manufacturer, or otherwise does not necessarily constitute or imply its endorsement, recommendation, or favoring by the United States Government or any agency thereof. The views and opinions of authors expressed herein do not necessarily state or reflect those of the United States Government or any agency thereof. 